\title{
Micro Transportation Systems: A Review
}

\author{
Phuc Hong Pham ${ }^{1}$, Dzung Viet Dao ${ }^{2}$ \\ ${ }^{1}$ School of Mechanical Engineering, Hanoi University of Science and Technology (HUST), Hanoi, Vietnam \\ ${ }^{2}$ Research Institute for Nanomachine System Technology, Ritsumeikan University, Kusatsu, Shiga, Japan \\ E-mail:phucph-fme@mail.hut.edu.vn \\ Received August 31, 2011; revised October 12, 2011; accepted October 22, 2011
}

\begin{abstract}
This paper summarized and reviewed recent studies of micro transportation systems (MTS) in the MEMS (Micro Electro-Mechanical System) field. Micro transportation systems can be identified and classified into three categories based on the contact types between the objects and the actuators (i.e. liquid-based, solidbased and air-bearing type). Their advantages and disadvantages were also analyzed and compared. The authors have proposed and developed three types of solid-based MTS utilizing electrostatic comb-drive actuators and ratchet mechanisms to drive the micro container in straight and curved paths. These MTSs have been fabricated with silicon-on-insulator (SOI)-MEMS technology and tested successfully. In the near future, MTSs can be applied in different fields such as medicine (to classify and test blood cells), in bioengineering (to capture, sort and combine bio-cells, DNA), or in micro robot systems.
\end{abstract}

Keywords: Micro Transportation System (MTS), Electrostatic Comb-Drive Actuator (ECA)

\section{Introduction}

By definition, a transportation system or a conveyance system is commonly used to transport or convey human, goods, devices etc. from a place to another.

Transportation systems are very important in daily life, as most people have to move everyday or even every hour for work, study, or shopping etc. Goods need to be conveyed to stores or to supermarkets after production. Some typical examples of transportation systems are vehicles network in cities with the size of kilometers, or automatic conveyance belts in factories with the size of meters. We can imagine how terrible our life would be if the transportation systems were not available.

Now, let us consider the case when the transported objects are in micrometer or nanometer scale, such as bio cells, DNA, biomedicine samples, micro/nano beads, carbon nano tube etc. Obviously, in order to transport or convey those small samples effectively, it is necessary to develop transportation systems having size proportionally to the size of the transported objects. Those transportation systems are refered to as Micro Transportation Systems (MTS).

In other words, micro transportation systems are transportation systems having the feature size in the micrometer scale, to move micro/nano objects from one place to another. The MTS should include fundamental features as in a macro transportation system, i.e. it should be able to move objects in straight and curved paths, to load and unload, or change the velocity of the objects in different applications.

\section{Classification of MTSs}

Micro/Nano Transportation Systems are important for conveying and sorting of small samples in assembly of micro systems [1], bioengineering [2], $\mu$-TAS (micro total analysis systems), robotics and automation, and so on. Up to date, there has been substantial number of reports on micro/nano transportation systems that can be grouped into three main categories corresponding to different contact types between the objects and the actuators, i.e., liquidbased, solid-based and air-bearing transportation systems.

\subsection{Liquid-Based Transportation Systems}

Liquid-based transportation systems are applied in nano bio-technology [2,3], $\mu$-TAS or micro fluidic systems [4-6] and can manipulate micro objects such as biological cells by pushing or pulling them. Electrostatic, electro-wetting, electrophoresis, dielectrophoresis, magnetic and chemical effects are usually used as the driving principle. However, it is difficult to obtain high accuracy of the movement with this type of transportation system. 


\subsection{Solid-Based Transportation Systems}

In solid-based transportation systems, objects directly contact with the solid actuators to receive the motion. Much work on these systems has been reported. In 2-D transportation system based on ciliary motion, objects were elevated and moved by the ciliary type thermal actuator arrays [7-14] or by permalloy magnetic actuator arrays [15] underneath. In array-driven ultrasonic micro-actuators [16], objects were conveyed by ultrasonic swing of the pillars array beneath. XY-plane transportation systems based on surface acoustic waves in piezoelectric substrate [17,18], 2-D micro conveyor based on electrostatic actuator $[19,20]$, inchworm motors with bidirectional XY electrostatic actuators [21,22] or transportation system based on vibrations of a slider combined with wedge mechanism [23], etc.

Almost of above-mentioned systems where the actuators are directly contacted with the moving objects have been realized by arrays of movable legs erected from the silicon surface [8-13], two clutch-drive actuators [21], or in-plane twisting actuators [22].

The legs and actuators are actuated by using different principles such as thermal, electrostatic, magnetic or piezoelectric actuation. In these cases, a complex driving technique requires at least two groups of actuators which are turned on and off at different times, alternately holding and driving the objects. But higher speed and smoother motion can be obtained with this driving.

\subsection{Air-Bearing Transportation Systems}

Air-bearing-based transportation systems were also seen in MEMS. The objects were levitated and moved by pneumatic air flow beneath [24-28]. In the micro transportations by using pneumatic or electromagnetic forces $[29,30]$ to create a cushion on which the mover levitates, there is not direct contact between objects and actuators (contact is free). Magnetic levitation can be achieved by using permanent magnets, electromagnets or diamagnetic (i.e. a superconductor) bodies. The main advantages of these types are low friction, the scratch and damage of the objects can be avoided, but the drawback is high sensitivity to the cushion thickness (i.e. load dependent) while the cushion thickness can be quite difficult to control.

In order to have a comprehensive view about each type of MTS developed so far, Table 1 shows some typical characteristics of the MTS in chronologic order based on three categories mentioned above.

\section{Solid-Based Micro Transportation System: Three Cases of Study}

The authors have been published three types of solid-based
MTS using electrostatic comb-drive actuators to drive micro containers in the defined path [31-34]. The first MTS is the tangential driving MTS, in which the driven micro containers are moved by tangential force [31]. The second is the perpendicular driving MTS, which drives micro containers by the perpendicular driving force, i.e. the moving direction of the container is perpendicular to the actuation direction [32,33]. The perpendicular MTS with novel design and faster movement of the container has been improved and tested in [34].

Main configuration and characteristics of three types of MTS will be described as below:

\subsection{Tangential Micro Transportation System}

Figure 1 shows the working principle of the tangential MTS. When applying a periodic voltage $\left(V_{12}\right)$ between fixed electrodes (pad (2)) and movable comb fingers (pad (1); note that pad (1) is connected to movable comb fingers through the beams), the movable fingers will move back and forth due to electrostatic force and elastic force of the beams. The left and right ratchet racks are connected to the movable combs of actuators, so they can move together. These ratchet racks are engaged to two sides of the micro container at the same time. The driving voltage is applied to the left and right actuator in the way so that their motions are in opposite directions. When the right ratchet actuator moves up, it drives the micro container to move up, while down movement of the left ratchet actuator leads to slide between the teeth of the micro container and of the ratchet actuator. The micro container can not move back due to the ratchet teeth arrangement.

Figure 2 shows the tangential MTS after fabrication. In this work [31], the movement of the micro container has been tested with voltage $V p p=100 \mathrm{~V}$ and driving frequency ranges from $5 \mathrm{~Hz}$ to $40 \mathrm{~Hz}$. The velocity of the container was proportional to the driving frequency, and the maximum obtained value was about $0.708 \mathrm{~mm} / \mathrm{sec}$.

\subsection{Perpendicular Micro Transportation System}

A structure of the ratchet-actuator and the container are shown in Figure 3. The fabrication perpendicular MTS and micro container are shown in Figure 4.

When applying a periodic voltage $\left(V_{12}\right)$ between fixed electrodes (pad (2) and movable comb fingers (pad (1)), the movable fingers will move forward and backward in lateral direction (i.e. horizontal direction) due to electrostatic force and the elastic force of the beams. The driving voltage is applied to the left and right comb actuator in the way so that the motions of the left and right ratchet racks are in opposite directions. When the right ratchet rack moves to the left, the left ratchet moves to the right at the same time with the same displacement, the wings of the container will rotate inward around the elastic 
Table 1. Overview of some recent micro transportation systems.

\begin{tabular}{|c|c|c|c|c|}
\hline Authors & Principle & $\begin{array}{l}\text { Maximum } \\
\text { velocity }\end{array}$ & $\begin{array}{l}\text { Displacement } \\
(\mu \mathrm{m}) \text { per cycle }\end{array}$ & $\begin{array}{l}\text { Dimensions and } \\
\text { power consumption }\end{array}$ \\
\hline $\begin{array}{l}\text { Pister et al., } \\
1990 \text { [24] }\end{array}$ & $\begin{array}{l}\text { Pneumatic air-bearing (low friction levitation). } \\
\text { Driving by electrostatic force. }\end{array}$ & $0.1-1 \mathrm{~mm} / \mathrm{s}$ & $\begin{array}{c}100-500 \\
\text { (at } f=1-2 \mathrm{~Hz})\end{array}$ & Not specified \\
\hline $\begin{array}{l}\text { Ataka et al., } \\
1993 \text { [8] }\end{array}$ & $\begin{array}{l}\text { Array of thermobimorph polyimide legs. } \\
\text { Electrical heating (asynchronous) }\end{array}$ & $0.5 \mathrm{~mm} / \mathrm{s}$ & $\begin{array}{c}80 \\
(f<f c=10 \mathrm{~Hz})^{*}\end{array}$ & $\begin{array}{l}8 \times 2 \times 16 \text { legs at } 500 \mu \mathrm{m} . \\
\text { Total size: } 5 \times 5 \mathrm{~mm}^{2} .33 \mathrm{~mW}\end{array}$ \\
\hline $\begin{array}{l}\text { Konishi et al., } \\
1994 \text { [25] }\end{array}$ & $\begin{array}{l}\text { Array of pneumatic valves. Electrostatic } \\
\text { actuation. }\end{array}$ & Not specified & Not specified & $\begin{array}{l}9 \times 7 \text { valves at } 100 \times 200 \mu \mathrm{m}^{2} . \\
\text { Total size: } 2 \times 3 \mathrm{~mm}^{2}\end{array}$ \\
\hline $\begin{array}{l}\text { Liu et al., } \\
1995[15]\end{array}$ & $\begin{array}{l}\text { Array for magnetic in-plane flap actuators. } \\
\text { External magnet for actuation (synchronous) }\end{array}$ & $2.6 \mathrm{~mm} / \mathrm{s}$ & $500\left(f_{c}=40 \mathrm{~Hz}\right)$ & $\begin{array}{l}4 \times 7 \times 8 \text { flaps at } 1400 \mu \mathrm{m} . \\
\text { Total size: } 10 \times 10 \mathrm{~mm}^{2}\end{array}$ \\
\hline $\begin{array}{l}\text { Suh et al, } \\
1997[12]\end{array}$ & $\begin{array}{l}\text { Array of thermobimorph polyimide legs. } \\
\text { Thermal and electrostatic actuation (asyn- } \\
\text { chronous) }\end{array}$ & $0.2 \mathrm{~mm} / \mathrm{s}$ & $\begin{array}{c}10(f=1 \mathrm{~Hz}) . \mathrm{fc} \approx 30 \mathrm{~Hz} \text { for } \\
\text { thermal actuation }\end{array}$ & $\begin{array}{l}\quad 8 \times 8 \times 4 \text { legs at } 430 \mu \mathrm{m} . \\
\text { Total size: } 10 \times 10 \mathrm{~mm}^{2} .20 \mathrm{~mW}\end{array}$ \\
\hline $\begin{array}{l}\text { Hirata et al, } \\
1998 \text { [28] }\end{array}$ & Pneumatic (air jets) & $\begin{array}{c}50 \mathrm{~mm} / \mathrm{s} \\
\text { (flat object) }\end{array}$ & Not specified & $\begin{array}{l}\text { 2x10 splits at } 50 \mu \mathrm{m} \text {. Size of slider: } \\
3 \times 3 \mathrm{~mm}^{2} \text {. Total size: } 20 \times 30 \mathrm{~mm}^{2}\end{array}$ \\
\hline $\begin{array}{l}\text { Kladitis et al., } \\
\quad 1999 \text { [13] }\end{array}$ & $\begin{array}{l}\text { Array of erected Si legs. Thermal actuation } \\
\text { (asynchronous) }\end{array}$ & $0.0075 \mathrm{~mm} / \mathrm{s}$ & $3.75\left(f<f_{c}=3 \mathrm{~Hz}\right)$ & $\begin{array}{c}96 \text { legs at } 270 \mu \mathrm{m} . \\
\text { Total size: } 10 \times 10 \mathrm{~mm}^{2} .175 \mathrm{~mW}\end{array}$ \\
\hline $\begin{array}{l}\text { Ruffieux et al., } \\
1999 \text { [14] }\end{array}$ & $\begin{array}{l}\text { Array of non-erected Si legs. Piezoelectric or } \\
\text { thermal actuation }\end{array}$ & Not specified & 20 & $\begin{array}{l}125 \text { triangular cells (legs) at } 400 \mu \mathrm{m} \\
(300 \mu \mathrm{m}) . \text { Chip } \approx 18 \mathrm{~mm}^{2}\end{array}$ \\
\hline $\begin{array}{l}\text { Ebefors et al., } \\
2000[10,11]\end{array}$ & $\begin{array}{l}\text { Array of erected Si legs. Thermal actuation } \\
\text { of polyimide joints (asynchronous) }\end{array}$ & $12 \mathrm{~mm} / \mathrm{s}$ & $48(f=250 \mathrm{~Hz})$ & $\begin{array}{l}\text { 2x6 legs at } 500 \mu \mathrm{m} \text {. Size of Si object: } \\
\qquad 14 \times 7 \times 0.5 \mathrm{~mm}^{3} .216 \mathrm{~mW} / \mathrm{leg}\end{array}$ \\
\hline $\begin{array}{l}\text { Yeh et al., } \\
2002[21]\end{array}$ & Bidirectional electrostatic actuation & $4 \mathrm{~mm} / \mathrm{s}$ & $\begin{array}{l}2(f c \text { is high-kilohertz } \\
\text { range) }\end{array}$ & $\begin{array}{l}\text { Total size of one motor: } 3 \times 1 \mathrm{~mm}^{2} \text {. } \\
\text { Power density: } 190 \mathrm{~W} / \mathrm{m} 3\end{array}$ \\
\hline $\begin{array}{l}\text { Kim et al., } \\
2005 \text { [22] }\end{array}$ & Electrostatic in-plane twisting actuation & $3 \mu \mathrm{m} / \mathrm{s}$ & $0.12(f c=1.68 \mathrm{kHz})$ & Total size: $7 \times 7 \mathrm{~mm}^{2}$ \\
\hline $\begin{array}{l}\text { Wu et al., } \\
2006[9]\end{array}$ & $\begin{array}{l}\text { Thermal bimorph actuation of polyimide } \\
\text { layer }\end{array}$ & $0.0015 \mathrm{~mm} / \mathrm{s}$ & $0.2-0.3($ at $f c=5 \mathrm{~Hz})$ & $\begin{array}{l}\text { Total size: } \\
900 \times 100 \times 4.5 \mu \mathrm{m}^{3}\end{array}$ \\
\hline $\begin{array}{l}\text { Chung et al., } \\
2007 \text { [4] }\end{array}$ & $\begin{array}{l}\text { Liquid-based using micro bubble fluidics. } \\
\text { Electrowetting-on-dielectric actuation }\end{array}$ & Not specified & Not specified & $\begin{array}{l}\text { Size of each electrode: } \\
\qquad 500 \times 500 \mu \mathrm{m}^{2}\end{array}$ \\
\hline $\begin{array}{c}\text { Pham et al., } \\
\text { 2006-2010 [31-33] }\end{array}$ & $\begin{array}{l}\text { Solid-based using electrostatic actuation and } \\
\text { ratchet mechanism }\end{array}$ & $0.708 \mathrm{~mm} / \mathrm{s}$ & $10-20\left(f_{c}=20 \mathrm{~Hz}\right)$ & Size of each module: $6 \times 6 \mathrm{~mm}^{2}$ \\
\hline $\begin{array}{l}\text { Dao et al., } \\
2010 \text { [34] }\end{array}$ & $\begin{array}{l}\text { Solid-based using electrostatic actuation and } \\
\text { ratchet mechanism }\end{array}$ & $1 \mathrm{~mm} / \mathrm{s}$ & $20(f c=50 \mathrm{~Hz})$ & Size of each module: $6 \times 6 \mathrm{~mm}^{2}$ \\
\hline
\end{tabular}




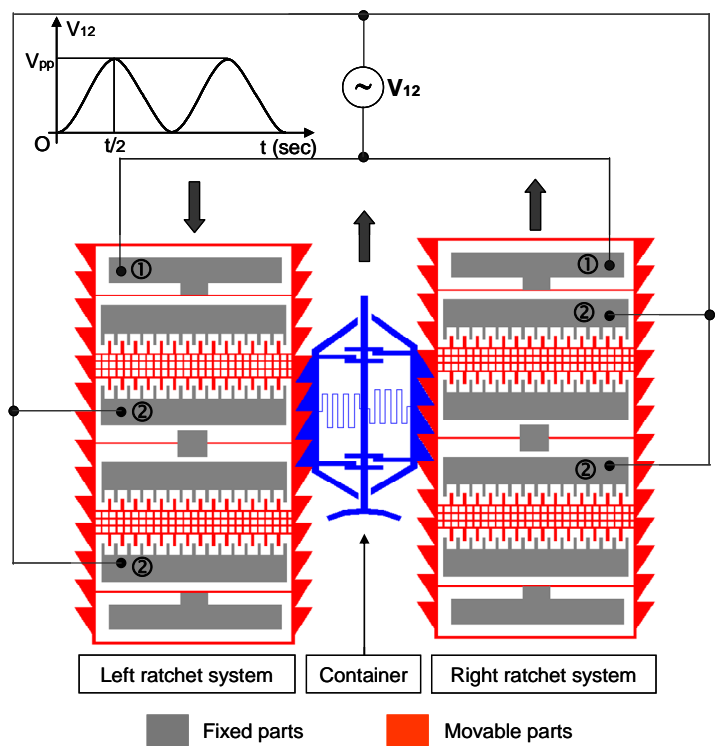

Figure 1. An electrical diagram for creating a straight movement of the micro container in the tangential MTS.

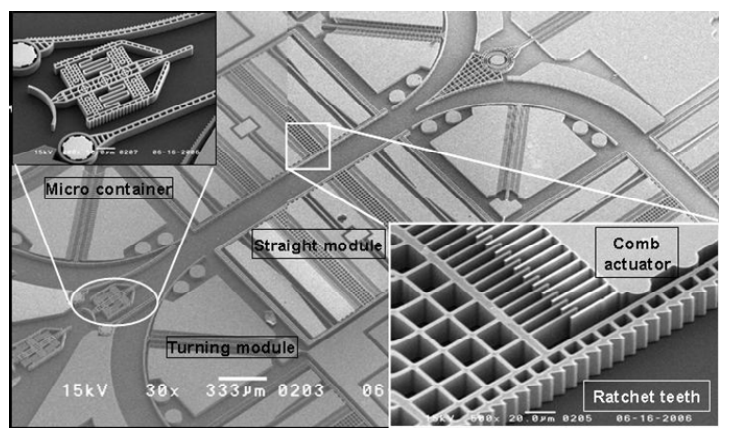

Figure 2. SEM image of the tangential MTS.

points due to electrostatic force. As a result, the container is pushed to move in vertical direction. Therefore, the antireverse hairs also move in vertical direction. The free end of anti-reverse hairs slides on the teeth of ratchet rack in forward direction only. Solid arrows in Figure 3 indicate the movement directions of ratchet racks and of the micro container. Next, when the driving voltage is reduced to zero, the two ratchet racks move outward and return to the initial positions due to elastic force of the beams. The micro container will not move back due to four anti-reverse hairs of the container engaged in the ratchet racks. In order to guarantee forward movement of the container, after each cycle, the container or, in other words, the antireverse hair should move at least one pitch of the ratchet teeth.

In our experiments, various driving frequencies ranging from $1 \mathrm{~Hz}$ to $20 \mathrm{~Hz}$ were used to accelerate the micro container up to $0.2 \mathrm{~mm} / \mathrm{sec}$. A power consumption at a frequency $f=10 \mathrm{~Hz}$, bias voltage $V_{0}=50 \mathrm{~V}(\mathrm{VPp}=100$ V) can be calculated to be about $55.7 \mathrm{~mW}[32,33]$. In the both types, each module of MTS has a size of $6 \times 6 \mathrm{~mm}^{2}$.

\subsection{The Improved Perpendicular Micro Transportation System}

Different from the work mentioned in paragraph 3.2, in this improved type of MTS, the container (Figures $\mathbf{5}$ and $\mathbf{6}$ ) has been newly designed. In the container, an elastic joint of the driving wings in previous design is replaced by spring system, and therefore, the driving wings can rotate easier with larger angle without the risk of being broken due to overloading or fatigue failures problems. Thanks to this improvement, the improved container could stand longer than one hour operational test at velocity of $1 \mathrm{~mm} /-$ sec without any problems observed. In this experiment, driving voltage and frequency were $140 \mathrm{~V}$ and $50 \mathrm{~Hz}$, respectively [34].

In our work, the container with a length, width and thickness of $450 \mu \mathrm{m}, 250 \mu \mathrm{m}$ and $30 \mu \mathrm{m}$, respectively, moves unidirectional in straight and curved paths. The

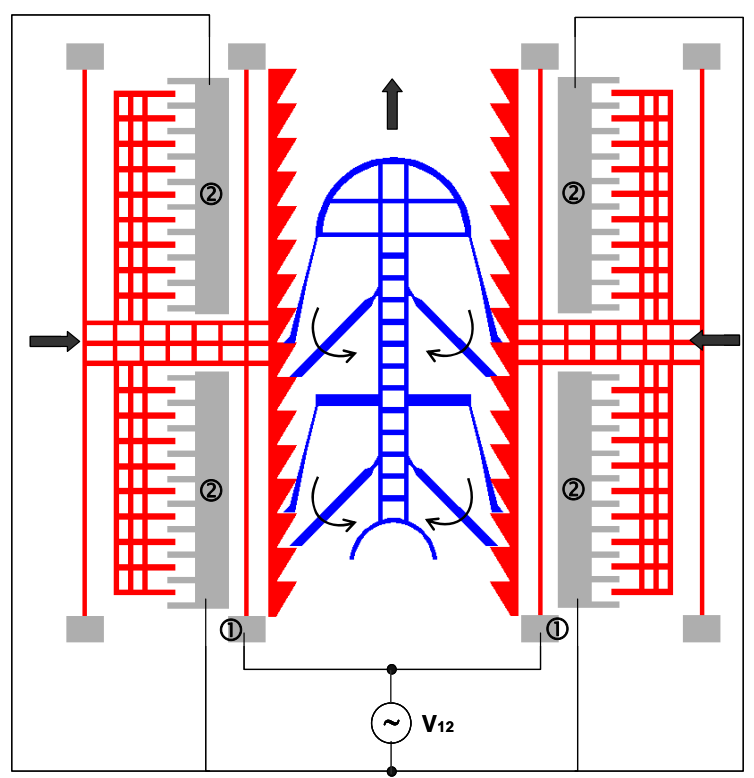

Figure 3. A working principle of the micro container in the perpendicular MTS.

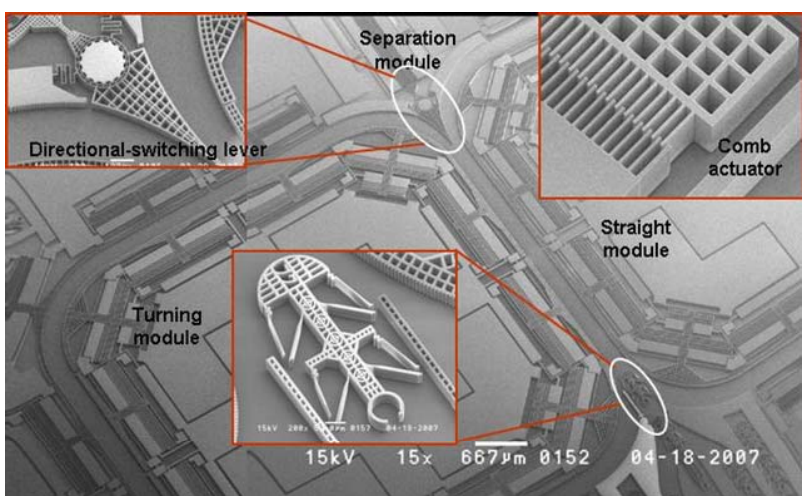

Figure 4. SEM image of the perpendicular MTS. 


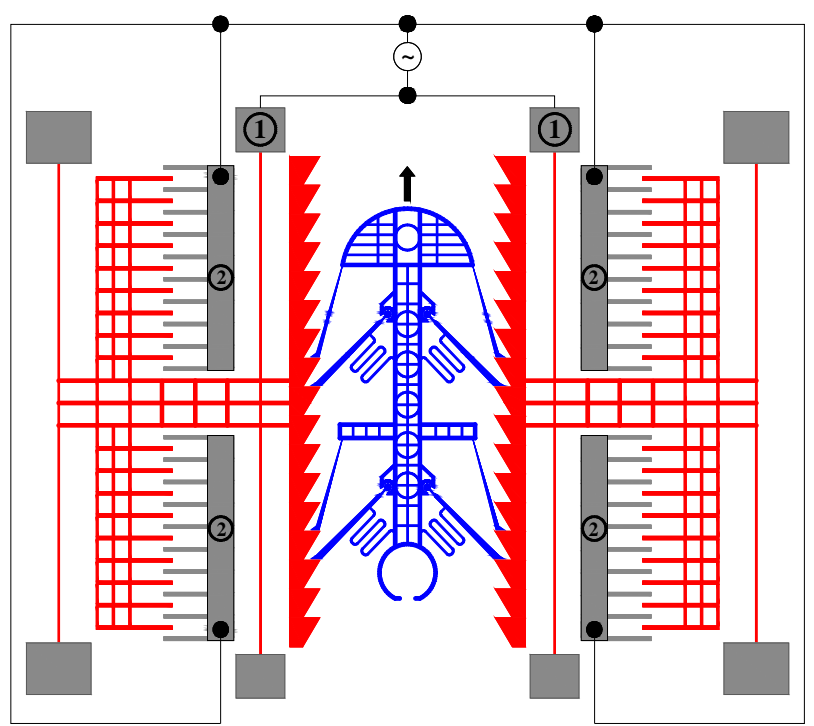

Figure 5. A working principle of the improved perpendicular MTS with new container's structure.

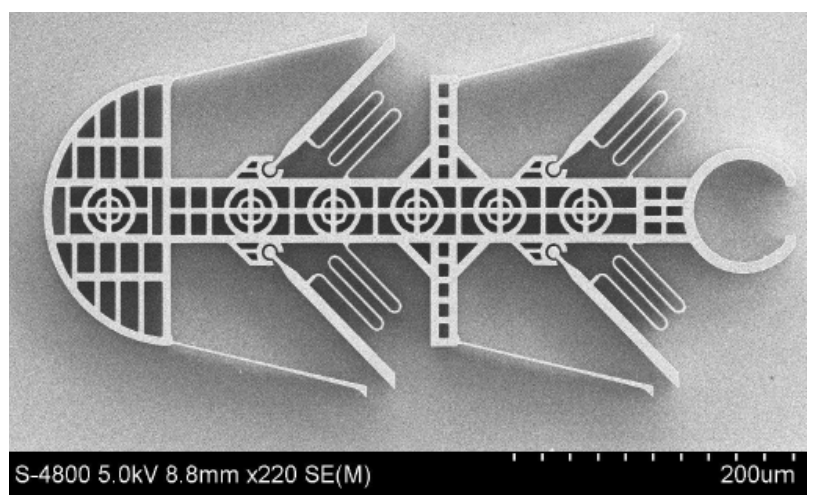

Figure 6. SEM image of new container in the improved perpendicular MTS.

velocity of the container can be changed by varying the frequency and/or amplitude of the driving voltage. The MTS including several of basic modules with the same size has been fabricated from SOI (silicon-on-insulator) wafer by utilizing silicon micromachining technology with only one mask.

The advantages of proposed MTS using electrostatic comb-drive actuators are simple configuration and control, small size, robust and can be batch fabricated by the bulk micromachining process.

\section{Discussion and Conclusions}

While the macro transportation systems have been developing well over hundreds years and are operating effecttively in daily life to transport people and goods, the system to convey micro samples are still an attractive research topic in MEMS field. In order to transport or convey micro samples efficiently, it is obviously necessary to build the MTS with dimensions or scale similar to the transported objects so that the system can be manipulated, checked and characterized in small working areas of the micro world, such as under optical microscope, inside SEM (scanning electron microscope), inside AFM (atomic force microscope), or under other measurement instruments of micro/nano research fields. Here, similarity in scale also includes the other features of the systems, such as movement velocity, accuracy, movement step, etc.

To achieve high performance and low cost micro transportation systems, it is important to create small size device with simple configuration, simple control and using standard fabrication technology. The design of the MTS should be flexible so that the system can be assembled or extended to different configurations conveniently. During the design process of a device, the trade-off between the range of stepping motion and power consumption, accuracy and cost, etc. must be taken into consideration. Therefore, design and trial fabrication of novel structures are the challenges and motivation in MEMS research.

In the last few years, the authors have reported three types of solid-based silicon MTS utilizing the electrostatic actuation and ratchet mechanism. In order to facilitate the flexible development of sophisticated MTS, we introduce the functional modules included starting or loading module, straight module, turning module, T-junction or separation module, ending module, etc. Each module was designed to achieve a specific moving task, i.e. the straight and turning modules were used to drive the containers in straight and turning paths, respectively. The T-junction module allows the container to turn left or right. The loading and ending modules were for convenient loading of the containers to the MTS and storing them after it finished the task respectively. All modules had the same dimensions and design rule so that they could be assembled together to form different MTS configuretions for different applications.

As the suggestion for future work, one of the potential applications of our MTS is in biochemical analysis. For example, the micro/nano samples are loaded and reacted on the containers, and moved continuously to the checkpoints, where these samples are evaluated optically or electrically before going to the T-junction modules to separate or classify. Then, good samples will be carried to the ending module or store-room for the next experiments and the others will be rejected.

\section{Acknowledgements}

The authors gratefully acknowledge to the Vietnam National Foundation for Science and Technology Development (NAFOSTED) for funding (Code: 107.01.26.09). 


\section{References}

[1] H. Van Brussel, J. Peirs, D. Reynaerts, A. Delchambre, G. Reinhart, N. Roth, M. Weck and E. Zussman, "Assembly of microsystems," Annals of the CIRP, Vol. 49 No. 2, 2000, pp. 451-472. doi:10.1016/S0007-8506(07)63450-7

[2] M. C. Tarhan, R. Yokokawa, F. O. Morin, S. Takeuchi and H. Fujita, "Sorting and Direct Transportation of Target Molecules by Bio-Molecular Selectivity and Motor Function," Technical Digest of the 20th IEEE International Conference on Micro Electro Mechanical Systems, Nürnberg, 22-25 May 2007, pp. 23-26.

[3] E. Altintas, K. F. Bohringer and H. Fujita, "Micromachined Linear Brownian Motor: Net-Unidirectional Transport of Nanobeads by Tamed Brownian Motion with Electrostatic Rectification," Technical Digest of the 20th IEEE International Conference on Micro Electro Mechanical Systems, Nürnberg, 22-25 May 2007, pp. 839-842.

[4] S. K. Chung, Y. Zhao, U. C. Yi and S. K Cho, "Micro Bubble Fluidics by Electrowetting on Dielectric and Ultrasonic Excitation for Micro Bubble Tweezers,” Technical Digest of the 20th IEEE International Conference on Micro Electro Mechanical Systems, Nürnberg, 22-25 May 2007, pp. 31-34.

[5] S. K. Cho, H. Moon, and C. -J. Kim, "Creating Transporting, Cutting and Merging of Liquid Droplets by Electrowetting-Based Actuation for Digital Microfluidic Circuits,” Journal of Microelectromechanical Systems, Vol. 12, No. 1, 2003, pp. 70-80. doi:10.1109/JMEMS.2002.807467

[6] K.-S. Yun and C.-J Kim, "Low-Voltage Electrostatic Actuation of Droplet on Thin Superhydrophobic NanoTurf,” Technical Digest of the 20th IEEE International Conference on Micro Electro Mechanical Systems, Nürnberg, 22-25 May 2007, pp. 139-142.

[7] M. Ataka, M. Mita and H. Fujita, "The Layer-Built Sensor/Actuator Integrated Array for the 2D Feedback Conveyance”, Technical Digest of the 20th IEEE International Conference on Micro Electro Mechanical Systems, Nürnberg, 22-25 May 2007, pp. 35-38.

[8] M. Ataka, A. Omodaka, N. Takeshima and H. Fujita, "Fabrication and Operation of Polyimide Bimorph Actuators for a Ciliary Motion System," Journal of Microelectromechanical Systems, Vol. 2, No. 4, 1993, pp. 146150. doi:10.1109/84.273089

[9] Chien-Tai Wu and Wensyang Hsu, "Design and Fabrication of an Electrothermal Microactuator for Multi-Level Conveying,” Journal of Microelectromechanical Systems, Vol. 12, No. 4, 2006, pp. 293-298.

[10] T. Ebefors, J. Mattsson, E. Kalvesten and G. Stemme, “A Micro Motion System Based on Polyimide Joint Actuators," Proceedings of EUROSENSORS XII, Southampton, 13-16 September 1998, pp. 391-394.

[11] T. Ebefors, J. Ulfstedt-Mattsson, E. Kalvesten and G. Stemme, "A Robust Micro Conveyer Realized by Arrayed Polyimide Joint Actuators," Journal of Micromechanics and Microengineering, Vol. 10, No. 3, 2000, pp. 337-349.

\section{doi:10.1088/0960-1317/10/3/307}

[12] J. Suh, S. Glader,R. Darling,C. Storment and G. Kovacs, "Organic Thermal and Electrostatic Ciliary Microactuator Array for Object Manipulation,” Sensors Actuators A, Vol. 58, No. 1, 1997, pp. 51-60. doi:10.1016/S0924-4247(97)80224-5

[13] P. E. Kladitis, V.M. Bright, K. F. Harsh and Y. C. Lee, "Prototype Microrobots for Micro Positioning in a ManuFacturing Process and Micro Unmanned Vehicles," Proceedings of the 12th IEEE International Micro Electro Mechanical System Conference, Orlando, 17-21 January 1999, pp. 570-575.

[14] D. Ruffieux and N. F. de Rooij, “A 3DOF Bimorph Actuator Array Capable of Locomotion,” Proceedings of the 13th European Conference on Solid-State Transducers, The Hague, 12-15 September 1999, pp. 725-728.

[15] C. Liu, T. Tsai, Y. C. Tai, W. Liu, P. Will and C. M. Ho, "A Micromachined Permalloy Magnetic Actuator Array for Micro Robotics Assembly Systems," Proceedings of International Conference on Solid-State Sensors and Actuators, Sweden, 25-29 June 1995, pp. 328-331.

[16] T. Furuhata, T. Hirano and H. Fujita, “Array-Driven Ultrasonic Microactuators," Proceedings of International Conference on Solid-State Sensors and Actuators, San Francisco, 24-27 June 1991, pp. 1056-1059.

[17] T. Shigematsu and M. K. Kurosawa, "XY Surface Acoustic Wave Motor with Nanometer Resolution,” Proceeding of 21st Sensor Symposium, Baltimore, 3-4 November 2004, pp. 237-240.

[18] T. Hata, H. Tsuyoshi, D. V. Dao and S. Sugiyama, “Theoretical and Experimental Study on Micro Fluidic Actuator Utilizing Surface Acoustic Wave," International Symposium on Flexible Automation, Osaka, 10-12 July 2006, pp. 120-123.

[19] M. Edo, Y. Watanabe, O. Morita, H. Nakazawa and E. Yonezawa, "Two-Dimensional Micro Conveyer with Integrated Electrostatic Actuators,” The 12th IEEE International Conference on Micro Electro Mechanical Systems, Orlando, 17-21 January 1999, pp. 43-48.

[20] T. Y. Harness and R. A. Richard, "Characteristic Modes of Electrostatic Comb-Drive X-Y Microactuators,” Journal of Micromechanics and Microengineering, Vol. 10, No. 1, 2000, pp. 7-14. doi:10.1088/0960-1317/10/1/302

[21] R. Yeh, S. Hollar and K. S. J. Pister, “Single Mask, Large Force, and Large Displacement Electrostatic Linear Inchworm Motors," Journal of Microelectromechanical Systems, Vol. 11, No. 4, 2002, pp. 330-336. doi:10.1109/JMEMS.2002.800937

[22] S. H. Kim, et al., "High-Resolution Inchworm Linear Motor Based on Electrostatic Twisting Microactuators," Journal of Micromechanics and Microengineering, Vol. 15, No. 9, 2005, pp. 1674-1682. doi:10.1088/0960-1317/15/9/009

[23] I. Fujimasa, "Micromachines, a New Era in Mechanical Engineering,” Oxford University Press, Oxford, 1996, pp. 115-117.

[24] K. S. J. Pister, R. S. Fearing and R. T. Howe, “A Planar 
Air Levitated Electrostatic Actuator System," Proceedings of the IEEE 5th Workshop on Micro Electro Mechanical Systems, 1990, pp. 67-71.

[25] S. Konishi and H. Fujita, “A Conveyance System Using Air Flow Based on the Concept of Distributed Micro Motion Systems," IEEE Journal of Microelectromechanical Systems, Vol. 3, No. 2, 1994, pp. 54-58. doi:10.1109/84.294321

[26] Y. Mita, S. Konishi and H. Fujita, "Two Dimensional Micro Conveyance Systems with through Holes for Electrical and Fluidic Interconnection,” Proceedings of International Conference on Solid State Sensors and Actuators, Chicago, 16-19 June 1997, pp. 16-19. doi:10.1109/SENSOR.1997.613575

[27] Y. Fukuta, M. Yanada, A. Ino, Y. Mita, Y. A. Chapuis, S. Konishi and H. Fujita, "Conveyor for Pneumatic TwoDimensional Manipulation Realized by Arrayed MEMS and its Control," Journal of Robotics and Mechatronics, Vol. 16, No. 2, 2004, pp. 163-170.

[28] T. Hirata, T. Akashi, A. Bertholds, H. P. Gruber, A. Schmid, M. -A. GrCtillat, O. T. Guenat and N. F. de RooiJ, "A Novel Pneumatic Actuator System Realized by MicroElectro-Discharge Machining," Technical Digest of the 11th IEEE International Conference on Micro Electro Mechanical Systems, 1998, pp. 160-165.

[29] Y.-K. Kim , M. Katsurai and H. Fujita "Fabrication and testing of a micro superconducting actuator using the Meissner effect," Proceedings of Ninth International Workshop on Micro Electromechanical Systems, Napa Valley, 11-14 February 1990, pp. 61-66.
[30] H. Nakazawa, Y. Wantanabe, O. Morita, M. Edo, M. Yushina and E. Yonezawa, "Electromagnetic Micro-Parts Conveyer with Coil-Diode Modules,” Technical Digest, Proceedings of 16th International Conference on Solid State Sensors and Actuators, Sendai, 7-10 June 1999, pp. 1192-1195.

[31] P. H. Pham, D. V. Dao, S. Amaya, R. Kitada and S. Sugiyama, "Straight Movement of Micro Containers Based on Ratchet Mechanism and Electrostatic Comb-Drive Actuators," Journal of Micromechanics and Microengineering, Vol. 16, No. 12, 2006, pp. 2532-2538. doi:10.1088/0960-1317/16/12/003

[32] P. H. Pham, D. V. Dao and S. Sugiyama, "Micro Transportation System (MTS) with Large Movement of Containers Driven by Electrostatic Comb-Drive Actuators," Journal of Micromechanics and Microengineering, Vol. 17, No. 10, 2007, pp 2125-2131. doi:10.1088/0960-1317/17/10/026

[33] P. H. Pham, L. B. Dang and H. N. Vu, "Micro Robot System with Moving Micro-Car Driven by Electrostatic CombDrive Actuators," Microsystem Technologies, Vol. 16, No. 4, 2010, pp. 505-510. doi:10.1007/s00542-010-1017-9

[34] D. V. Dao, P. H. Pham and S. Sugiyama, “A Novel Micro Transportation System with Fast Movement of a Micro Container Based on Electrostatic Actuation and a Ratchet Mechanism,” Journal of Micromechanics and Microengineering, Vol. 20, No. 11, 2010. doi:10.1088/0960-1317/20/11/115026 